\title{
APPLICATION OF PROBLEM BASED LEARING MODEL IN ANALYZING NATIONALISM OF POETRY "DI BAWAH LAYAR" BY D. ZAWAWI IMRON
}

\author{
M. Yusup Sulaeman \\ SMK Al Ibrohimiyah, Ciranjang \\ Email: ucupwaras@yahoo.com
}

\begin{abstract}
This article discusses the students' ability to analyze elements of nationalism, themes, and the message. The study was conducted on students of class X SMK Al-Ibrohimiyah Cianjur. Methods used in research, classroom action research with test instruments, observation sheets and questionnaires. The study was conducted in three cycles. The results showed an increase in (1) the effectiveness of learning increases, in the first cycle of class is still noisy, then in cycle II has started not rowdy, and on cycle III is conducive; (2) students' interest in appreciating the literary work is increasing, in cycle I students are active only as small, in cycle II almost half and in cycle III become most; and (3) students' ability in analyzing the element of nationalism, theme and poetry mandate increased, in the first cycle the average score of the students was 66.19 on the second cycle reached 75.95 and in the third cycle reached 91.66. It was concluded that the application of learning problem based learning model on learning to analyze the theme and the message of the students of class X of SMK AlIbrohimiyah Cianjur can improve the effectiveness, student interest and student learning outcomes.
\end{abstract}

Keywords: problem based learning, nationalism, structural and poetry.

\section{PENDAHULUAN}

Pembaruan kurikulum adalah pembaruan suatu zaman ketika dinamika pendidikan sekolah semakin banyak tuntutan dari berbagai aspek yang perlu dicapai, dan pembaruan ini mewarisi dampak besar pada kehidupan masyrakat. Masyarakat sebagai agen pembaruan mulai menjelmakan inovasiinovasi dari tahun ke tahun karena merasa tertangtang terhadap zaman yang akan dihadapi, salah satunya yang harus dihadapi masyarakat adalah perkembangan dunia pendidikan yang semakin tahun semakin kentara daya saingannya, baik ditinggkat nasional maupun internasional.

Sejarah perjalan kurikulum pendidikan sejak tahun 1945, kurikulum pendidikan nasional telah mengalami pembaruan, yaitu pada tahun 1947, 1952, 1964, 1968, 1975, 1984, 1994, 2004, 2006 dan 2013. Pembaruan tersebut merupakan konsekuensi logis dari terjadinya pembaruan sistem politik, sosial budaya, ekonomi, dan iptek dalam masyarakat berbangsa dan bernegara.

Dalam mengikuti pembaruan tersebut kurikulum 2013 proses pembelajaran (dari siswa diberi tahu menjadi siswa mencari tahu) dan proses penilaian (dari berbasis proses out put menjadi berbasisi proses dan out put). Pengembangan Pembangunan karakter siswa dalam proses pembelajaran salah satunya menggunakan model pembelajaran problem based learning. Menurut Tan dalam Rusman (2011:229) pembelajaran problem based learning merupakan inovasi dalam pembelajaran karena dalam PBL kemampuan berpikir siswa betul-betul dioptimalkan melalui proses kerja kelompok atau tim yang sistematis, sehingga siswa dapat memberdayakan, mengasah, menguji, dan 
mengembangkan kemampuan berpikirnya secara berkesinambungan.

Materi ajar dalam bahasa dan sastra Indonesia ada dua rumpun ilmu, bahasa dan sastra. Sastra tidak dapat dipisahkan dari struktur pembangunnya, hal ini disebabkan karena menurut Teeuw (2003:21) sastra adalah alat untuk mengajar, buku petunjuk, buku intruksi atau pengajaran yang ditelaah oleh manusia, baik dari segi struktur pembangun ataupun dari makna karya sastra tersebut. Sastra juga mempunyai unsur-unsur pembentuk di dalamnya yang memiliki arti bila kita ketahui dan kaji secara teliti.

Mengingat pentingnya ilmu sastra, terutama pemahaman melalui pengkajian akan bermanfaat bagi perkembangan ilmu kesusastraan di dunia pendidikan. Pembelajaran sastra dalam pendidikan formal perlu dikembangkan dan dilestarikan dari apa yang sudah ada sekarang ini. Pembelajaran sastra di lembaga pendidikan formal pada dasarnya adalah suatu pembelajaran yang bertujuan untuk memperkenalkan serta memberikan pemahaman mengenai makna yang terkandung dalam karya sastra kepada siswa dan mengajak siswa untuk menghargai atau berapresiasi terhadap pengalaman-pengalaman yang terkandung di dalamnya.

Karya sastra memiliki beberapa jenis diantaranya puisi, prosa, dan drama. Menurut Mc Caulay, Husdons dalam Aminuddin (2009: 134) puisi adalah salah satu cabang sastra yang menggunakan kata-kata sebagai media penyampaian untuk membuahkan ilusi dan imajinasi, sepertihalnya lukisan yang menggunakan garis dan warna dalam menggambarkan gagasan pelukisnya. Puisi bagi anak adalah sarana yang tepat untuk mengekspresikan penghayatannya terhadap berbagai ragam kehidupan. Puisi memiliki jenis atau keinginan yang hampir sama dengan jenis karya sastra lainnya yakni berkomunikasi antara manusia dengan manusia, manusia dengan alam serta manusia dengan Tuhan.
Puisi sebagai salah satu karya sastra media penuangan perasaan atau pengalaman penulis memlalui rangakaian kata yang disusun sedemikian rupa sehingga menghasilkan karya seni tulis yang estetik .

Dewasa ini sebuah fenomena muncul dalam dunia pendidikan, khususnya dalam pembelajaran bahasa dan sastra Indonesia pengajaran sastra seakan seperti terpinggirkan, bahkan sudah sejak lama sastra tidak dianggap sebagai ilmu, ada beberapa yang memposisikan sastra sebagai hiburan. Di sekolah-sekolah pun sastra dianggap sebagai pelengkap pelajaran bahasa. Sering jam pelajaran sastra digantikan oleh pelajaran tatabahasa. Cara pengajaran sastra monoton karena yang dipelajari berkutat dengan rumus-rumus pantun, gurindam, dan kelahiran-kematian pengarang sementara sastra yang sedang hangat di sekitar, tidak disentuh. Para guru sastranya banyak yang tidak memahami sastra sehingga tidak menggiring siswa untuk lebih mengenal sastra. Hal itu tentu saja menimbulkan kekacauan dalam dunia pengajaran sastra. Akibatnya, tingkat apresiasi siswa terhadap sastra semakin berkurang dan menurun.

Salah satu contoh kongkret yang dapat dilihat dari menurunnya tingkat apresiasi siswa terhadap sastra adalah berkurangnya apresiasi siswa terhadap karya sastra drama. Pada saat ini siswa hanya sekedar tahu sepintas mengenai drama, tanpa mengenal dan mempelajarinya secara lebih dalam dan menelaahnya. Sedangkan pemahaman terhadap strukturaslime yang terkandung dari puisinya sama sekali tidak dihiraukan. Padahal hal itu sangat berguna sekali bagi siswa, karena pada drama terdapat strukturstruktur pembangun yang akan menjembatani pada pemahaman di dalam drama tersebut.

Dilihat dari permasalahan di atas maka penerapan model problem based learning dalam proses pembelajaran perlu diterapkan karena adalah akan memberikan nuansa berbeda dalam proses pembelajaran yang semula pembelajaran sastra monoton karena 
guru yang lebih banyak aktif, sehingga efektivitas pembelajaran kurang kondusif sehingga menimbulkan minat siswa terhadap pembelajaran sastra rendah dan mengakibatkan nilai hasil belajarnya rendah. Ada bayak model-model pembelajaran yang dapat di gunakan sehingga diharapkan siswa pada proses pembelajaran yang akan berperan lebih aktif dan akan menimbulkan apresiasi sastra pada siswa meningkat sebab mereka akan mencari dari berbagai sumber sehingga nilai hasil belajarnyapun akan meningkat. Berdasarkan fenomena tersebut maka yang dibahas dalam artikel ini yaitu penerapan dalam pembelajaran menganalisis unsur nasionalisme, tema dan amanat puisi di kelas X SMK Al-Ibrohimiyah Cianjur tahun 20152016.

\section{METODE}

Metode yang digunakan dalam penelitian adalah metode Penelitian Tindakan Kelas (PTK). Penelitian Tindakan Kelas (PTK) menurut Arikunto dkk. (2006:16) penelitian tindakan kelas ini terdiri dari empat komponen, yakni perencanaan, pelaksanaan, pengamatan (observasi) dan refleksi. Adapun penelitian yang dilaksanakan terdiri dari tiga siklus yang tiap siklusnya terdiri dari dua pertemuan. Penelitian dilaksanakan selama tingga minggu selama bulan Juni 2016.

Objek penelitian adalah siswa kelas $\mathrm{X}$ AP SMK A-Ibrohimiyah sebanyak 21 orang yang terdiri dari 3 laki-laki dan perempuan 18 orang. Adapun subjek pada penelitian ini adalah peningkatan efektivitas pembelajaran supaya tidak monoton, peningkatan minat siswa dalam mengapresiasi puisi serta peningkatan hasil belajar siswa dalam menganalisis unsur nasionalisme, tema dan amanat puisi di kelas X SMK Al-Ibrohimiyah menggunakan model pembelajaran problem based learning.

Instrumen yang digunakan dalam penelitian adalah tes, lembar observasi guru dan siswa serta angket kemudian mempersiapkan silabus dan Rencana Pelaksanaan
Pembelajaran (RPP) yang disesuaikan dengan sekolah tersebut.

\section{HASIL DAN PEMBAHASAN}

\section{Efektivitas Pembelajaran}

Di dalam proses pembelajaran siklus I keadaan kefektifan kelas kurang kondusif sebab keadaan kelas masih gaduh dan ramai, siswa kurang memperhatikan guru. Dari jumlah keseluruhan 21 siswa, siswa yang memperhatikan dan fokus pada pembelajaran sebanyak 12 siswa $(57,14 \%)$ sedangkan yang tidak memperhatikan dan berbicara dengan temannya sebanyak 9 siswa $(42,85 \%)$.

Menurut Arikunto (61:2010) dalam penelitian tindakan kelas harus ada peningkatan atau perbaikan mutu, kinerja, kualitas, proses dan hasil belajar pada siswa. Berdasarkan pendapat tersebut maka peneliti melakukan beberapa perbaikan di siklus II untuk mewujudkan hal-hal tersebut. Pada pembelajaran sikllus II keadaan keefektifan kelas mulai membaik dibandingkan dengan siklus II karena dari kesulurah siswa sebanyak sebanyak 15 siswa $(71,42 \%)$ sedangkan yang tidak memperhatikan dan berbicara dengan teman sebangkunya ketika pembelajaran sebanyak 6 siswa $(28,57 \%)$.

Pada pembelajaran siklus III keadaan keefektifan kelas sudah baik dan kondusif karena ketika pembelajaran dilaksanakan dari jumlah keseluruhan 21 siswa, siswa yang memperhatikan 19 siswa $(90,47 \%)$ sedangkan yang kurang memperhatikan dan berbicara dengan teman sebangkunya selama pembelajaran berjumlah 2 siswa $(69,52 \%)$. Untuk memudahkan deskripsi di atas disajikan dalm diagram pada halaman berikut.

Dalam diagram tampak keadaan keefektifan kelas di atas dapat disimpulkan bahwa dari setiap siklusnya ada peningkatan ke arah positif sebab dari siklus I ke siklus II dan ke siklus III jumlah siswa yang memperhatikan pembelajaran semakin bertambah dan jumlah siswa yang berbicara 
dengan teman sebangkunya semakin berkurang, jadi kegiatan tindakan kelas sudah berhasil dan berhenti sampai di siklus III serta penerapan menggunakan model pembelajaran problem based learning dapat meningkatkan efektivitas pembelajaran ini sesuai dengan yang disebutkan oleh Hosnan (2014:299) bahwa model pembelajaran problem based learning dapat mengembangkan keadaan siswa menjadi aktif sehingga menjadikan kelas menjadi kondusif.
$(47,61 \%)$ yang membaca, dan sebagiannya lagi ada yang membaca dengan diselangi mengobrol sebanyak 10 siswa $(47,61 \%)$ dan yang paling menunjukan minatnya kurang yaitu ada 1 orang siswa $(4,76 \%)$ melamun memandang kaca jendela kelas ketika diberi waktu untuk membaca puisi. Kejadian lain ditunjukan oleh siswa bahwa minat belajarnya sedikit karena ketika diberi waktu untuk presentasi hanya ketua kelompok dari setiap kelompoknya saja yang bersedia kedepan menjelaskan yakni sebanyak 5 siswa

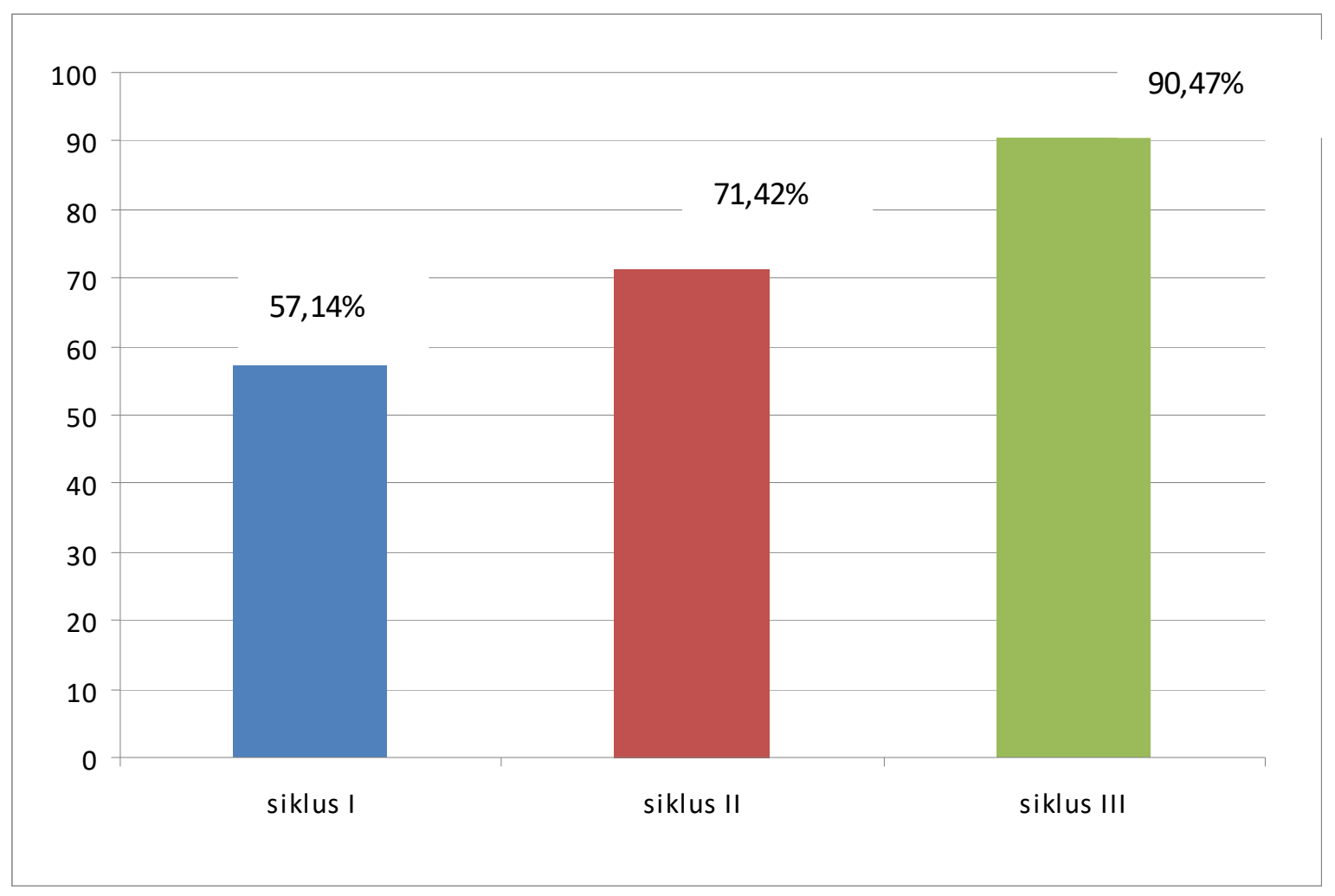

Diagram 1: Pembandingan Keefektifan Pembelajaran

\section{Minat Siswa}

Minat siswa dalam belajar pada siklus I masih kurang, sebab keadaan siswa ketika proses pembelajaran berlangsung masih sedikit hal ini ditunjukan oleh sikap siswa ketika pembelajaran berlangsung mereka kurang antusias dalam pembelajaran, pada waktu guru memberikan pertanyaan seputar materi yang respon menjawab hanya 2 orang $(9,52 \%)$ sedangkan 19 siswa $(90,47 \%)$ malah terdiam, kemudian ketika mereka disuruh untuk membaca puisi hanya 10 siswa
$(23,8 \%)$ sedangkan angota dari setiap kelompok mereka malah diam yakni sebanyak 16 siswa $(76,19 \%)$.

Berdasarkan deskripsi di atas ternyata pembelajaran siklus I di dalam minat siswa sangat rendah. Untuk menyalesaikan permasalahan tersebut peneliti memperbaiki pada siklus II dengan mengacu pada teori menurut Zaenal (108:2007) bahwa permasalahan di dalam penelitian tindakan kelas harus diselesaikan secara kolaboratif untuk memecahakan masalah yang ada di penelitian tersebut. Sedangkan menurut Arikonto 
(63:2010) kolaboratif dalam memecahkan permasalahan yang berada dalam penelitian tindakan kelas yaitu adanya kerja sama antara peneliti dan observer untuk mendiskusikan bagaimana cara untuk mengatasi masalah tersebut.

Pada pembelajaran siklus II minat siswa terhadap pembelajaran sudah meningkat dibandingkan dengan siklus I karena keadaan siswa ketika proses pembelajaran berlangsung mulai merespon ditunjukan oleh sikap siswa ketika pembelajaran berlangsung. Ketika mereka disuruh untuk membaca puisi, dari 21 siswa $16(71,42 \%)$ siswa membaca puisi dengan khusu serta ketika mereka membaca puisi jumlah siswa yang kadang-kadang terhenti dan mengobrol dengan rekan satu bangkunya kini berjumlah 6 siswa $(28,57 \%)$, serta pada pembelajaran siklus II tidak ada lagi siswa yang tertidur ketika diberi waktu untuk membaca puisi. Kemudian ketika guru memberikan pertanyaan seputar puisi dan nasionalisme kepada siswa jumlah yang aktif merespon kini bertambah dibandingkan dengan siklus I menjadi menjadi 10 siswa $(47,61 \%)$ sedangkan yang masih kurang aktif sebanyak 11 siswa $(52,38 \%)$, kejadian lain ditunjukan oleh siswa bahwa minat belajarnya mulai meningkat dibandingkan dengan siklus I karena ketika guru memberikan waktu untuk presentasi antar kelompok kini tidak hanya ketua kelompoknya saja yang ke depan mempresentasikan namun dengan anggotanya dan kegiatan diskusi kelas mulai aktif, siswa yang aktif pada kegiatan diskusi kelas sebanyak 14 siswa $(66,66 \%)$ dan hanya 7 siswa $(33,33 \%)$ yang masih diam ketika diskusi kelas.

Pada pembelajaran siklus III minat siswa dalam pembelajaran sudah tinggi ini ditunjukan karena keadaan siswa ketika proses pembelajaran berlangsung mereka merespon ditunjukan oleh sikap siswa ketika pembelajaran berlangsung, ketika mereka disuruh untuk membaca puisi, dari keseluruhan siswa 19 siswa $(90,47 \%)$ membaca dengan khusu sendangkan 2 siswa $(6,67 \%)$ mereka masih berbicara dengna teman sebangku disela-sela membaca puisi masih suka mengobrol dengan teman sebangkunya, ketika guru memberikan pertanyaaan mengenai seputar puisi, 19 siswa $(90,47 \%)$ aktif dalam menjawab pertanyaan tersebut dan 2 $(9,52 \%)$ siswa masih diam, kemudian ketika diberi waktu untuk diskusi kelas 19 (90,47\%) siswa aktif dalam kegiatan diskusi tersebut baik bertanya, menyanggah ataupun menambahkan dan 2 siswa $(9,52 \%)$ masih diam ketika diskusi kelas.

Dari deskripsi di atas dapat disimpulkan bahwa minat siswa dalam belajar mengalami peningkatan, ini terbukti dari jumlah siswa yang membaca naskah drama dengan fokus, siswa yang aktif ketika guru memberikan pertanyaan seputar puisi, siswa yang aktif ketika di beri waktu untuk diskusi kelompok dari siklus I ke siklus II dan ke siklus III semakin bertambah dan meningkat. Berdasarkan hal tersebut disimpulkan bahwa kegiatan tindakan kelas sudah berhasil dan berhenti sampai di siklus III serta penerapan model pembelajaran problem based learning dapat meningkatkan minat siswa dalam menganalisis puisi, sesuai dengan yang disebutkan oleh Hosnan (2014:299) bahwa an model pembelajaran problem based learning dapat mengembangkan kemampuan siswa menjadi kritis dan aktif sehingga mereka mampu memecahkan masalah sendiri.

\section{Hasil Belajar}

Pada pembelajaran siklus I nilai hasil belajar siswa rendah yakni dari jumlah keseluruhan 21 siswa nilai rata-rata perindikator yaitu nasionalisme sebesar 14,33, teman sebesar 14,76 dan amanat sebsar 12,57. Sementara hasil nilai rata-rata komulatif siklus I yang diperoleh siswa yaitu 66,19. Hal tersebut disebabkan karena siswa belum terbiasa menganalisis unsur nasionalisme, tema dan amanat pada puisi menggunakan model pembelajaran problem based learning sehingga pembelajaran kurang kondusif. Kendala tersebut selanjutnya direfleksi dan hasilnya diaplikasikan pada siklus II. 
Dengan berbagai perbaikan atas kekurangan pada siklus I, pelaksanaan pembelajaran pada siklus II mendapatkan nilai rata-rata perindikator yaitu nasionalisme sebesar 17,61, tema sebesar 17,85 dan amanat sebesar 14,52. Sementara hasil komulatif sikulus II yaitu 75,95 namun pada siklus II masih ada 9 orang yang nilainya kurang dari KKM yaitu 55 sebanyak 1 orang, 60 sebayak 2 orang, 65 sebanyak 1 orang dan 70 sebanyak 5 orang sedangkan nilai KKM di SMK Al-Ibrohimiyah Cianjur adalah 75. Perbaikan dilaksanakan dengan cara membagi siswa dalam bentuk kelompok-kelompok yang lebih kecil terdiri dari dua orang supaya guru lebih mudah dalam memberikan arahan dan bimbingan serta pembelajaran menjadi kondusif.

Dengan perbaikan pada siklus II maka pada siklus III kegiatan pembelajaran berjalan lancar serta hasil belajar yang diperoleh dari jumlah keseluruhan siswa mendapatkan nilai rata-rata perindikator yaitu nasionalisme sebesar 28,57, teman sebesar 19,28, dan amanat sebesar 18,80 . Sementara hasil nilai rata-rata komulatif pada siklus III yaitu 91,66 dan hasil tersebut menunjukan bahwa ada peningkatan hasil belajar siswa dari siklus I ke siklus II dan ke siklus III.

Dengan deskripsi di atas dapat disimpulkan bahwa kegiatan tindakan kelas sudah berhasil dan berhenti sampai di siklus III serta penerapan model pembelajaran problem based learning dapat meningkatkan hasil belajar siswa dalam menganalisis unsur nasionalisme, tema dan amanat pada puisi sesuai dengan yang disebutkan oleh Hosnan (2014:299) bahwa model pembelajaran problem based learning dapat mengembangkan kemampuan siswa menjadi kritis dan aktif sehingga mereka mampu memecahkan masalah sendiri.

\section{Respon Siswa}

Respons siswa terhadap pembelajaran diungkap melalui angket tertutup. Setelah mengikuti pembelajaran menganalisis unusr nasionalisme, tema dan amanat pada puisi menggunakan model pembelajaran problem based learning, berdasarkan angket yang terkumpul diperoleh data tentang respon belajara siswa yang beraneka ragam dan tercermin dalam berbagai aspek sebagai berikut.

Sebagian besar 15 siswa $(71,42 \%)$ sangat setuju dan sebayak 6 siswa $(28,42 \%)$ setuju dengan adanya pembelajaran sastra khususnya puisi disekolah menggunakan model pembelajaran problembased learning. Hal ini menunjukan bahwa penerapan model pembelajaran problem based learning terhadap pembelajaran puisi sangat disukai oleh siswa.

Sebagian besar 18 siswa $(85,71 \%)$ yang setuju dan 3 siswa $(14,28)$ sangat setuju terhadap pembelajran mengalaisi puisi menggunakan model pembelajaran problem based learning siswa menjadi menyukai puisi. Hal ini menunjukan bahwa penerapan model pembelajaran problem based learning terhadap pembelajaran menganalisis puisi sangat sangat meningkatkan minat siswa terhadap puisi.

Hampir setengahnya 10 siswa $(47,61 \%)$ menyatakan sangat setuju, sebayak 5 siswa $(23,8 \%)$ menyatakan setuju, sebayak 5 siswa $(23,8 \%)$ menyatakan tidak seutu dan 1 siswa $(4,76 \%)$ sangat tidak setuju terhadap bahasa yang digunakan dalam puisi mudah di pahami. Hal ini mejawab bahawa bahasa yang terdapat dalam puisi dapat dipahami oleh siswa.

Sebagian besar 17 siswa $(80,95 \%)$ menyatakana sangat setuju, sebaya 4 siswa $(19,04 \%)$ menyatakan setuju bahawa dalam menganalisis unsur nasionalisme perlu dilakukan untuk menjembatani pada makna yang dikandung dalam puisi tersebut.

Sebagian besar 19 siswa $(90,47 \%)$ menyatakan sangat setuju dan 2 siswa (9,52\%) menyatakan setuju terhadap penerapan model Problem Based Learning 
membuat keadaan menjadi kondusif. Hal ini menunjukan bahwa penerapan model pembelajaran problem based learning terhadap pembelajaran menganalisis unusr nasionalisme, tema dan amanat pada puisi membuat keadaan kelas menjadi kondusif ketika pembelajaran berlangsung.

Sebagian besar 13 siswa $(61,9 \%)$ menyatakan sangat setuju dan 8 siswa $(38,09 \%)$ menyatakan setuju bahwa amanat sebuah puisi dapat dijumpai dalam kehidupan nyata. Hal ini menujukankan bahwa amanat puisi dapat dijumpai oleh siswa dalam kehidpuan merka sehari-hari.

Hampir setengahnya 10 siswa $(47,61 \%)$ menyatakan sangat setuju, 9 siswa $(42,85 \%)$ menyatakan setuju dan 2 siswa $(9,52 \%)$ menyatakan tidak setuju terhadap pembelajaran menganalis unsur nasionalisme, tema dan amanat pada puisi menggunakan model pembelajaran problem based learning. Hal ini menunjukan dengan menggunakan model pembelajaran problem based learning dalam menganalisis unsur nasionalisme, teman dan amat pada puisi dapat diterapakan dalam pembelajran menganalisis puisi.

Sebagaian besar 11 siswa $(52,38 \%)$ menyatakan sangat setuju, 9 siswa $(42,85 \%)$ menyatakan setuju dan 1 siswa $(4,76 \%)$ menyataakan tidak setuju terhadapa penerapan model Problem Based Learning terhadap pembelajaran menganalisis puisi menjadi tidak monoton. Hal ini menunjukan bahwa model Problem Based Learning membuat pembelajaran menganalisis puisi yang asalnya monoton menjadi tidak monoton.

Sebagian besar 12 siswa $(57,14 \%)$ menyatkan sangat setuju dan 9 siswa $(42,58 \%)$ menyatakan setuju model Problem Based Learning minat mempelajari menganalisis puisi menjadi meningkat. Hal ini menunjukan bahwa model Problem Based Learning dapat meningkatkan minat siswa terhadapa pembelajaran menganalisis puisi.
Sebagian besar 11 siswa $(52,38 \%)$ menyatakan sangat setuju, 8 siswa $(38,09 \%)$ menyatakan setuju, 1 siswa $(4,76)$ menyatakan tidak setuju dan 1 siswa $(4,76)$ menyatakan sangat tidak setuju setelah menggunakan model Problem Based Learning dalam menganalisis unsur nasionalisme, tema dan amanat pada puisi menjadi lebih mudah. Hal ini dapat menunjukan bahwa penerapan model Problem Based Learning dalam pembelajaran menganalisis unsur nasionalisme, tema dan amanat pada puisi menjadi lebih mudah.

Hasil respon 21 siswa mengenai Hasil angket atau skala sikap yang diberikan memiliki jumlah keseluruhan sebanyak 569 selanjutnya diukur menggunakan rumus yang sudah ada dan hasilnya sebagai berikut:

Skor jumlah rata-rata angket siswa sebanyak 3,3 selanjutnya hasil pengukuran ini diinterprestasikan dengan klasifikasi jumlah skor seluruh peserta didik, skor rata-rata nilai peserta didik lebih dari 2,5 maka disimpulkan bahwa skor subjek peserta didik bersifat positif terhadap tindakan pembelajaran yang diberikan selama penelitian mengenai materi menganalisis unsur nasionalisme, tema dan amanat yang terkandung dalam puisi menggunakan model pembelajaran problem based learning.

Dari hasil analisis angket di atas dapat disimpulkan bahwa penerapan model pembelajaran problem based learning terhadap pembelajaran menganalisis unsur nasionalisme, tema dan amanat pada puisi membuat siswa mudah mencari unsur nasionalisme, tema dan amanat, memahami puisi tersebut dan mereka yakin nilainya tidak akan turun setelah guru menggunkan model pembelajaran problem based learning selama proses pembelajaran berlangsung.

\section{SIMPULAN}

Berdasarkan hasil pengumpulan dan pengolahan data penerapan model pembelajaran problem based learning dalam 
pembelajaran menganalisis unsur nasionalisme, tema dan amanat pada puisi di kelas $\mathrm{X}$ SMK Al-Ibrohimiyah Cianjur tahun 20152016 disimpulkan hal-hal sebagai berikut.

Keadaan keefektifan kelas dapat disimpulkan bahwa dari setiap siklusnya ada peningkatan ke arah positif sebab dari siklus I ke siklus II, dan dari siklus II ke siklus III jumlah siswa yang memperhatikan pembelajaran semakin bertambah dan jumlah siswa yang berbicara dengan teman sebangkunya semakin berkurang. Jadi, kegiatan tindakan kelas sudah berhasil dan berhenti sampai di siklus III serta model pembelajaran problem based learning dapat meningkatkan efektivitas pembelajaran ini sesuai dengan yang disebutkan oleh Hosnan (2014:299) bahwa model pembelajaran problem based learning dapat mengembangkan keadaan siswa menjadi aktif sehingga menjadikan kelas menjadi kondusif.

Minat siswa dalam belajar mengalami peningkatan, ini terbukti dari jumlah siswa yang membaca puisi dengan fokus, siswa yang aktif ketika guru memberikan pertanyaan seputar puisi dan dari jumlah siswa yang aktif ketika di beri waktu untuk diskusi kelompok dari siklus I ke siklus II dan dari siklus II ke siklus III semakin bertambah dan meningkat dari itu dapat disimpulkan bahwa kegiatan tindakan kelas sudah berhasil dan berhenti sampai di siklus III serta penerapan model pembelajaran problem based learning dapat meningkatkan minat siswa dalam mengapresiasi puisi sesuai dengan yang disebutkan oleh Hosnan (2014:299) bahwa model pembelajaran problem based learning dapat mengembangkan kemampuan siswa menjadi kritis dan aktif sehingga mereka mampu memecahkan masalah sendiri.

Hasil belajar siswa dengan menggunakan model pembelajaran problem based learning dapat meningkatkan hasil belajar siswa dalam menganalisis unsur nasionalisme, tema dan amanat pada puisi karena hasil belajar siswa setiap siklusnya meningkat. Pada siklus I nilai rata-rata siswa sebesar 66,19 lalu pada siklus II nilai siswa meningkat menjadi 75,95 namun masih ada 9 orang yang memperoleh nilai di bawah KKM maka dilajutkan pada siklus III meningkat menjadi 91,66 serta seluruh siswa nilainya sudah melampaui KKM. Maka proses tindakan kelas sudah berhasil dan berhenti sampai di siklus III sesuai dengan yang disebutkan oleh Hosnan (2014:299) bahwa model pembelajaran problem based learning dapat mengembangkan kemampuan siswa menjadi kritis dan aktif sehingga mereka mampu memecahkan masalah sendiri.

Sehubungan dengan kesimpulan di atas, disajikan saran-saran kiranya dapat memberikan masukan dalam pembelajaran mengalaisis unsur nasionalisme, tema dan amanat pada sebuah karya sastra khususnya puisi.

Model pembelajaran problem based learning cocok diterapkan pada pembelajaran menganalisis unsur nasionalisme, tema dan amanat pada puisi karena dapat membuat keadaan kelas menjadi efektif, minat siswa menjadi tinggi dan hasil belajar siswa menjadi tinggi.

Siswa harus sering membaca berbagai macam puisi supaya tingkat pemahaman mereka lebih tinggi terhadap karya sastra khususnya puisi dan mengetahui unsur nasionalisme, tema dan amanat yang terkandung di dalamnya.

Untuk peneliti yang lain yang sebentar lagi akan menjadi pengajar, penelitian tindakan kelas dapat dikembangkan dalam pelaksanaan pembelajaran setelah menjadi seorang pengajar sebab tujuan penelitian tindakan kelas yaitu untuk meningkatkan sesuatu hal yang bermasalah dilingkungan pembelajaran. 


\section{DAFTAR PUSTAKA}

Aminuddin. 2009. Pengantar Apresiasi Karya Sastra. Bandung: Sinar Baru.

Arikunto, Suharsimi. 2010. Prosedur Penelitian Suatu Tindakan Praktis. Jakarta: Rineka Cipta. dkk. 2006. Penelitian Tindakan Kelas. Jakarta: Bumi Angkasa.

Aqib, Zainal. 2007. Penelitian Tindakan Kelas Untuk Guru. Bandung: Yrama Widya.

Hosnan. 2014. Pendekatan Saintifik dan Kontekstual dalam Pembelajaran Abad 21. Bogor: Ghalia Indonesia.

Rusman. 2011. Model-Model Pembelajaran Mengembangkan Profesionalisme Guru. Jakarta: Rajawali Pers.

Teeuw, A. 2003. Satera dan Ilmu Satera. Jakarta: Pustaka Jaya. 